DOI: http://dx.doi.org/10.33846/hn41204

http://heanoti.com/index.php/hn

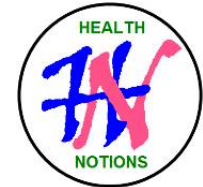

RESEARCH ARTICLE

URL of this article: http://heanoti.com/index.php/hn/article/view/hn41204

\title{
Program for Optimizing the Role of WPA to Reduce the Stigma and Discrimination PLWHA in The Community
}

\begin{tabular}{c} 
Sri Winarni ${ }^{\mathbf{1}}$, Wiwin Martiningsih ${ }^{2(\mathrm{CA})}$ \\
${ }^{2}$ Nursing Department, Poltekkes Health of Malang, swinkhamaisya@ gmail.com \\
\hline
\end{tabular}

\begin{abstract}
Stigma and discrimination remain significant obstacles in the management of HIV / AIDS prevention programs. The data shows there are stigma and discrimination within the health service, treatment is not going well. PLWHA tends to be ashamed and afraid to control or get medicine in the hospital, injustice to the provision of services, thus, low quality of care, and lack of respect for patients. The purpose of this study was to reduce the stigma and discrimination of HIV / AIDS patients in the community, through community empowerment programs. Long-term benefits were finding the right design to reduce stigma and discrimination toward HIV / AIDS patients, through community empowerment by integrating the concepts of social support, social networks, and social marketing. One group pretest-posttest design was used in this research. Seventy-five respondents were taken purposively. The intervention was "Optimizing Program of WPA's Role in reducing stigma and discrimination toward HIV AIDS patients in the community". The results showed that before and after the intervention, the average of community members did not have a negative attitude, did not perceived discrimination, and supported the equity. However, there were still hesitant and had a negative attitude within several community members to HIV / AIDS patient and the numbers decreased after the intervention. Based on the Wilcoxon signed-rank test, there were significant differences in negative attitudes, perceived discrimination, and support for equity before and after intervention with significance levels respectively $p=0.049, p=0.006$, and $p=0.000$. Intensive coordination and evaluation of activities are needed to ensure the sustainability of the WPA Optimization program.
\end{abstract}

Keywords: WPA optimization program; stigma; discrimination; HIV / AIDS

\section{Background}

\section{INTRODUCTION}

HIV-related stigma and discrimination are known to harm HIV prevention goals. Experiences of HIVrelated stigma and discrimination have been widely reported around the world and have been a barrier to the program's success. The stigma and discrimination in society have an impact on the denial of health services. Patients feel there is an injustice in the provision of services, and a lack of respect for patients. Then, all of this has an impact on the quality of care ${ }^{(1)}$. Stigma and discrimination can come from the community, health care providers, families, and even patients themselves. Even health workers with HIV can also get stigma and discrimination in their workplaces ${ }^{(2)}$. However, the essential stigma is from the community; therefore, community participation needs to help solve this problem.

The number of people with HIV in Blitar city until June 2018, 157 cases (94 living, 63 dead), with five issues per year. In 2017 there were 29 cases per year, 21 possession, and eight deaths, while in 2018, 15 cases per year, 14 living, one $\operatorname{dead}^{(3)}$. The number of points spread across three sub-districts: 49 instances in Kepanjenkidul, 52 in Sananwetan, and 54 in Sukorejo, two patients not identified. Based on the results of the study obtained problems related to HIV AIDS, especially is the high stigma and de-termination in the community in the form of dissolving, both by families and the community, fear of interacting, and reluctance to repatriate corpses in people suspected of HIV positive. The results of the meeting in Bapedda Blitar City reported stigma and discrimination that arise among the community, such as one example of a family bathing a family member who died of HIV without the help of neighbors around him. Should not happen if society does 
not give a negative stigma. They don't dare ask for help, maybe family members are embarrassed or indeed the community or neighbors don't dare use. The Blitar city government has tried to socialize about the disease, its prevention, its means of transmission, and fashionable training to bathe PLWHA (People Living with HIV/AIDS) in their neighborhoods. Fact in the field, although there are models who can wash corpses, families are less open, so do not know it.

Between 2011 and 2015, held World AIDS Day was with the theme "Getting to Zero: Zero New HIV Infection, zero discrimination, and zero AIDS-related deaths ${ }^{(4)}$. In this context, a global vision developed for all countries; working together towards zero, but the big question is how can we approach these ambitious targets (5). And now, we must work quickly to achieve the UNAIDS goal of 90-90-90. This ambitious goal seeks to ensure that 90 percent or more people living with HIV/AIDS (PLWHA) are aware of their HIV status; that 90 percent of those who are positive, receive HIV treatment; and that 90 percent of those who use the therapy achieve viral suppression ${ }^{(1)}$.

If achieving the zero discrimination target is not as expected, then 90909090 goals are challenging to achieve. So if stigma and discrimination persist, then patients don't want control, don't continue treatment, and don't want to meet others. It is challenging to open UP HIV status in others out of shame and fear because highrisk people do not want to do HIV tests. As reported in the latest PEPFAR Annual Report to Congress, stigma and discrimination remain significant obstacles in maintaining priority populations in HIV treatment services. Research on the psychosocial aspect of HIV-positive status shows that living with HIV is associated with a large amount of stress and depression. People with HIV/AIDS should also manage the stigma associated with HIV/AIDS. Even, they should tolerate treatment with adverse side effects, deal with rejection and social discrimination, and face the death of others on their social networks. Being HIV positive generally makes HIV part of a person's identity.

SRAN Document 2015-2019 emphasizes the integration of HIV \&amp; AIDS prevention efforts both vertically (centrally and regionally) and horizontally (across sectors and programs) in terms of governance, financing, human resource management, drug management and medical equipment, information system development, management and provision of health services and strengthening community participation ${ }^{(6)}$. Instilling a nature of concern in this community is indispensable. According to the results of the study ${ }^{(7)}$, some cadres can help counselors to find cases of HIV / people who are at risk of HIV. He can even take patients to the health care unit. So they finally want to do an HIV test. The role of these cadres is beneficial to counselors, because sometimes the workload of counselors is high, limited time because they are not in that community environment, causing counselors difficulty finding high-risk cases. Cadres (WPA/Warga Peduli AIDS) can play an optimal and less optimal role; this is by the results of a study from the Blitar City Health Office in June 2018.

Several programs aimed at lowering stigma and discrimination have been carried out. One of them is to design programs with the community involved. The empowerment of urban areas needs to be supported by the development and provision of vital health human resources, adequate financing, development of health promotion methods and technology, and aimed at changing people's behavior. So they don't have a negative stigma against HIV/AIDS patients and also don't discriminate. Current programs tend to be less evolved, and cadres are not functioning optimally, even complaints by counselors with heavy workloads ${ }^{(3)}$.

The technique of changing behavior with the target of society by modifying the theory concept of Social support, social network, and social marketing expert to help solve this problem (Stigma and discrimination against HIV/AIDS patients). Social support is functional of the relationship between 4 dimensions of support behavior: emotional support, instrumental support, informational support, and appraisal support. In comparison, the social network is a social network that refers to the relationship between people who may or may not provide social support. The concept of networking in social points for all relationships with other groups allows activities to run efficiently and effectively. Social marketing applies marketing techniques by using mass marketing and advertising to improve knowledge, change people's behavior and social. Mass media advertising marketing is television, radio, newspapers, magazines, websites, brochures, postcards, pamphlets, and others ${ }^{(8)}$. Some research has shown that social marketing support HIV test awareness campaign programs in the City of Baltimore. The campaign slogan "Live Long. Life is strong. Get Tested. Get Treatment" is designed to reduce anxiety and stigma common in the African American community. Thus it became a significant barrier to testing and treatment.

From the above explanation, the author wants to optimize community empowerment as a form of intervention to minimize the stigma that exists. Based on the "WPA Role Optimization Program in reducing Stigma and Discrimination in PEOPLE with HIV AIDS in Society". Then modify the concept of social support, social networking, and social marketing theory. The result evaluation of this program is how stigma exists in the community after the implementation of the program to support getting zero and 909090 goals.

\section{Purpose}

Explaining the effect of the "WPA Role Optimization Program" on stigma and discrimination in the community in HIV/AIDS patients, specifically 1) Identify stigma and discrimination in HIV/AIDS patients in 
the city before the implementation of the program, 2) implement the WPA Role Optimization Program in The Reduction of Stigma and Discrimination in HIV AIDS Patients, 3) identify stigma and discrimination in HIV/AIDS patients in the community after the implementation of the program, 4) analyze the influence of the WPA Role Optimization Program on Stigma and discrimination in the city in HIV/AIDS patients.

\section{METHODS}

The design used in this study was one group pretest-posttest design. Intervention in the form of the program "Optimizing the role of WPA In the reduction of Stigma and discrimination in HIV AIDS patients". Before the intervention, pretest respondents were given a pretest, after a posttest intervention to find out the stigma, and discrimination in society.

Intervention in the form of a WPA role optimization program was to integrate the concept of social support, social networking, and social marketing. Meanwhile, WPA management activities are evaluated after training and during the health counseling or promotion process. The population in this study was 154,714 people. While the sample was the people involved in the HIV AIDS control program, she was namely listening to radio broadcasts, knowing the banner of HIV AIDS prevention, and participating in the counseling program as many as 75 people. Sampling conduct using purposive sampling method based on the criteria that respondents: 1) present in counseling activities, 2) listen to the radio about HIV AIDS counseling, 3) Read banners about HIV AIDS prevention installed. The research conduct in Sananwetan sub-district of Blitar city, in July- September 2019.

The stigma assessment instrument using the HIV Stigma Scale consists of 18 question items divided into three domains 1) negative attitudes in people with HIV AIDS (negative statements no 1-8): scores 8 - 40, with the interpretation of results the higher the score, the more negative the HIV patient responds to, 2) perceived/perceived discrimination (negative statement no 9-14): score 6 - 30, with the interpretation of the result the higher the score, the higher the perceived discrimination against HIV patients and 3) Support for fair treatment of HIV/AIDS patients (positive statement no. 15-18): score $4-20$, with the interpretation of results the higher the score, the more supportive the justice of HIV patients. The questionnaire to measure HIV Stigma tested its validity and reliability ${ }^{(9)}$.

Data collection technique begins by applying for an ethics test to the Ethics Team, application for permission to the Head of Bakesbangpolinmas of Blitar city, application for approval to the Head of Blitar City Health Office, and Sananwetan District Office of Blitar City. Furthermore, conduct 1) Meetings/coordination between, Health Office, KPA, UPTD Puskesmas Sananwetan / Counselor, and WPA management, 2) Establishment of Group WA of WPA administrators, 3) Filling questioner Stigma scale for Sananwetan subdistrict community (Before treatment), 4) training on WPA (evaluated WPA knowledge at the end of training), 5) training result practice: WPA forms groups according to their respective regions and in conducting counseling activities accompanied by KPA and research team, Radio broadcast, installation of AIDS HIV Prevention Banner, 6) evaluation of WPA performance/observation, 7) charging questioner Stigma scale for Sananwetan sub-district community (After treatment).

The descriptive analysis aims to explain the stigma and discrimination that exists in society in every item presented in the form of narratives and tables. To find out the difference in stigma and discrimination before and after treatment using Wilcoxon Signed rank test, through the help of software product and service solution (SPSS) application program for windows version 17.

\section{RESULTS}

\section{Characteristics of Respondents}

The study's respondents were 75 people, with an average age of 46 years, the youngest 25 years and the oldest 64 years old, $89 \%$ female. The most Muslim respondents (90.7\%), education level $60 \%$ high school and above, $50 \%$ are housewives, and almost $60 \%$ of them play a role in society either as PKK members, cadres or chairman of the neighborhood.

\section{Stigma and Discrimination Before WPA Optimization Program}

Based on table 1, on the Negative Attitudes subscale, the average score of the negative attitude component is 15.48 (scores between $8-40$ ), while the average score of each negative attitude statement is 1.9 (strongly disagree until agree) in table 2. This indicates that the average person does not show a negative attitude towards PLWHA. However, 14 respondents showed hesitation and even agree with the negative attitude on PLWHA. One of the attitudes they agree with is "People with HIV should not have the same freedom as others/people don't have HIV". 
Table 1. Stigma scale results before intervention $(n=75)$

\begin{tabular}{cccc}
\hline Data & $\begin{array}{c}\text { Negative attitudes before } \\
\text { program intervention }\end{array}$ & $\begin{array}{c}\text { Perceived Discrimination } \\
\text { before the intervention }\end{array}$ & $\begin{array}{c}\text { Support of equity before } \\
\text { program intervention }\end{array}$ \\
\hline Average & 15.48 & 13.04 & 14.92 \\
Lowest & 8 & 6 & 4 \\
Highest & 33 & 24 & 20 \\
\hline
\end{tabular}

Table 2. Negative attitudes before intervention

\begin{tabular}{cc}
\hline Negative Attitudes Before Intervention & Amount \\
\hline $\begin{array}{c}\text { The average score of each negative attitude statement } \\
\text { Number of respondents (hesitative to agree) }\end{array}$ & 1.9 \\
\hline \multicolumn{3}{l}{ Table 3. Perceived discrimination before intervention } \\
\hline Perceived Discrimination before the intervention & Amount \\
\hline The average score of each statement & 2.17 \\
Number of respondents (hesitative to agree) & 18 \\
\hline
\end{tabular}

Table 4. Support for equity for PLWHA before intervention

\begin{tabular}{cc}
\hline Support for equity for PLWHA before the intervention & Amount \\
\hline The average score of each statement support equity & 3,7 \\
Number of respondents ( undecided/disagree) & 15 \\
\hline
\end{tabular}

Based on table 1, on the subscale of perceived discrimination, the average score is 13.4 (scores between 8 - 40), while the score of each perceived average discrimination statement is 2.17 (strongly disagree until agree) in table 3. This shows that the average person does not feel discrimination against PLWHA. However, 18 respondents indicated hesitation to even agree discrimination against PLWHA. An example of perceived discrimination includes "Most people won't buy food from sellers with HIV.AIDS.

Based on table 1, on the support for equity subscale, the average score is 14.92 (scores between $8-40$ ), while the average score of each statement of justice support is 3.7 (strongly disagree until agree) in table 4 . This shows that the average society, support equity for PLWHA. However, 15 people disagree and even hesitant to support justice on PLWHA, which can be seen from the statement 1) People with AIDS should be treated the same by health workers as people with other diseases and 2) People with HIV should be allowed to participate fully in social activities in the community.

\section{Implementation of "WPA Role Optimization Program"}

The implementation of the WPA optimization program includes:

1. Meeting ( KPA, Health Office of Blitar City, Counselor, Puskesmas, and WPA manager of Sananwetan subdistrict. (Social Support)

2. Training of Sananwetan Sub-District WPA Cadre (Social Support)

3. Establishment of WhatsApp Group of WPA and KPA administrators (Social Network)

4. Implementation of training results (Social Marketing) :

a. WPA administrators form groups according to their respective regions and in conducting counseling activities accompanied by KPA and research team (social network)

b. WPA administrators are PKK manager, Cadre Manager, Chairman of the neighborhood, religious group, teenager, and elderly.

c. Counseling/Campaigning/promotion by WPA administrators accompanied by KPA about stigma and discrimination:

- Group of 1, targeting 10 people, at House of The Chairman of WPA Gedog Village

- Group of 2, targeting 15 people, at Posyandu Gedog Sananwetan Village

- Group of 3, targeting 50 people, at Gedog Sananwetan District Hall

Health promotion used modules, leaflet, poetry (tembang mocopat). Methods: role play, playing (ice breaking, lectures, discussions, brainstorming).

5. Radio broadcasts (Social Marketing)

6. Banner installation (Social Marketing)

\section{Evaluation of WPA Management Training Results}

The results of the post-training evaluation of WPA administrators show that the seven indicators in the 
training module are well understood, that indicators are: 1) Information about the place of HIV Testing Services in Blitar City, 2) Knowledge about AIDS, 3) Myths and facts surrounding HIV, 4) How to avoid HIV, 5) Stigma and discrimination, 6) Acceleration Program for preventing HIV AIDS, 7) Warga Peduli AIDS (WPA) Concept.

The evaluation results in the form of field observation during the implementation of the program from 6 indicators are good, and assessment indicators are included: 1) Ability to convey material, 2) ability to answer questions, 3) media used, 4) Methods used, 5) appearance, 6) Audience interest

\section{Stigma and Discrimination After WPA Optimization Program.}

Table 5. Stigma scale after intervention $(n=75)$

\begin{tabular}{cccc}
\hline Data & $\begin{array}{c}\text { Negative attitudes before } \\
\text { program intervention }\end{array}$ & $\begin{array}{c}\text { Perceived Discrimination } \\
\text { after program intervention }\end{array}$ & $\begin{array}{c}\text { Support for equity after } \\
\text { program intervention }\end{array}$ \\
\hline Average & 14.07 & 11.63 & 16.92 \\
Lowest & 8 & 6 & 7 \\
Highest & 28 & 19 & 20 \\
\hline
\end{tabular}

Table 6. Negative attitudes after intervention

\begin{tabular}{cc}
\hline Negative Attitudes after Intervention & Amount \\
\hline The average score of each negative attitude statement & 1.8 \\
Number of respondents with negative statements of hesitation/agree & 8 \\
\hline
\end{tabular}

Based on table 5, on the Negative Attitudes subscale, the average score of the harmful attitude component is 14.07 (scores between $8-40$ ), while the average score of each negative attitude statement is 1.8 (with a score of $1-5$, strongly disagreeing to agree) in table 6. Suggests that after the intervention, the average person does not show a negative attitude towards PLWHA. However, there are still eight respondents who show skepticism and even agree with negative attitudes on PLWHA.

Table 7. Perceived discrimination after intervention

\begin{tabular}{ll}
\hline Perceived Discrimination after the intervention & Amount \\
\hline The average score of each statement & 1.9 \\
Number of respondents with a statement of hesitation/agree & 15 \\
\hline
\end{tabular}

Based on table 5, on the perceived discrimination subscale, the average score is 11.63 (scores between $8-40$ ), while in table 7 the score of each perceived average discrimination statement is 1.9 (with a score between $1-5$, strongly disagreeing until agreeing). This shows that the average person does not feel any discrimination against PLWHA. However, there were still 15 respondents who indicated hesitation to even agree with discrimination in PLWHA.

Table 8 Support for Justice After Intervention

\begin{tabular}{cc}
\hline Support for Justice to PLWHA after the intervention & Amount \\
\hline The average score of each statement & 4.2 \\
Number of respondents with a statement of hesitation/agree & 6 \\
\hline
\end{tabular}

Based on table 5, on the justice support subscale, the average score is 16.92 (scores between $8-40$ ), in table 8 the score of each statement of moderate justice support is 4.2 (with a score between $1-5$, strongly disagreeing until agreed). This shows that the average society supports justice for PLWHA. However, six people disagree or are hesitant to support justice on PLWHA, especially the statement about: People with AIDS should be treated the same by health officials as people with other diseases

\section{The Effect of Optimization Program on Stigma and Discrimination}

Table 9. Wilcoxon signed ranks test results

\begin{tabular}{cccc}
\hline & $\begin{array}{c}\text { Negative attitudes towards } \\
\text { HIV Patients after and } \\
\text { before program intervention }\end{array}$ & $\begin{array}{c}\text { Perceived Discrimination } \\
\text { after and before program } \\
\text { intervention }\end{array}$ & $\begin{array}{c}\text { Support for equity } \\
\text { treatment of PLWHA } \\
\text { after and before } \\
\text { program intervention }\end{array}$ \\
\hline Asymp. Sig. (2-tailed) & 0.049 & 0.006 & 0.000 \\
\hline
\end{tabular}


Based on the table above are significant differences in negative attitudes before and after intervention with a significance level of $\mathrm{p}=0.049$. The difference from negative attitudes that previously scored an average of 15.48 decreased to 14.07 , which means that their negative attitude reduces towards PLWHA; they are more optimistic. Likewise, each component of the negative attitude statement from an average score of 1.9 to 1.8 , and people who were hesitant or agreed negative attitudes decreased from 14 to 8 people.

There is also a significant difference between perceived discrimination. Either before or after intervention with a value of $\mathrm{p}=0.006$. They were also supported by data change in the average score of respondents before intervention 13.04. After the intervention of 11.63, the score of each statement before the moderate intervention was 2.2 and after that to 1.9. And 18 people who initially hesitated or still felt discrimination became 15 people.

There is a significant difference in support justice of PLWHA between before and after intervention with a value of $p=0.000$. The score of each statement before moderate intervention is 3.7. The score after that becomes 4.2. Fifteen people who were initially undecided or still did not support justice to 6 people.

\section{DISCUSSION}

\section{WPA's Role Optimization Program in Stigma Reduction and Discrimination in HIV / AIDS Patients}

The optimization program is still focused on the Gedog village area and will continue in 6 other villages. Financing and coordination are under the supervision of Blitar city health office and Sananwetan district holder. The principle of empowerment principles applied in this activity, such as 1) Volunteering: people who are voluntarily willing to attend counseling activities where this activity sometimes interferes with their routine. 2) accountability; some WPA managers are very responsible for their duties, organizing schedules, managing consumption, making invitations, making home visits if there are people who cannot attend without information, and also provide a quick response if needed ${ }^{(10)}$.

However, for the sustainability of activities, especially in areas that have not received treatment, intensive coordination is needed in addition to funding. Next, the activities will be carried out by the WPA administrators of each region through the assistance of the research team and the Health Office /KPA of Blitar city. 3) principles of respecting local wisdom in conducting activities, many special groups such as KWT, Pokja PKK, Tagana, Karang cadets, youth mosques, Posyandu activities, religious activities (study, yasinan, etc.) that targeted at health promotion.

Cross-sectoral coordination, cross-program, and WPA is a form of social support needed to support the implementation of programs in the reduction of stigma. Social support is available content of relationships that categorized into four types of supportive behaviors or actions: 1) Emotional support involves the provision of empathy, love, trust, and caring, 2) Instrumental support consists in providing assistance and services directly to people in need, 3) Information support is the provision of advice and information that a person can use to address problems, 4) Assessment support involves providing useful information for self-evaluation, in other words, constructive feedback and affirmations ${ }^{(11)}$. All of these supportive behaviors have been applied in this study.

The formation of WhatsApp groups consisting of policyholders and WPA administrators is one of the implementations of the social network that leads to all relationships with other people or groups that allow activities to run efficiently and effectively. For a time other than in-person meetings, WA can be relied upon to know each other, inform each other, remind each other, and assist each other in implementing or addressing one issue.

This program has implemented the concept of social marketing, namely product, price, place, and promotion $^{(11)}$. This product is a desirable behavior related to the reduction of stigma and discrimination in HIV patients. The price in this activity has the meaning of barriers to voluntarily lowering stigma and discrimination. It is a place to promote stigma reduction through home visits, radio, banner installations, and poetry readings. So promotion is a strategy to convey a message so as not to provide stigma or discrimination that tends to motivate behavioral sedation through engaging media and appropriate methods. WPA respondents and administrators have some suggestions that in the promotion of HIV do not show scarThis product is a desirable behavior related to the reduction of stigma and discrimination in HIV patients. The price in this activity has the meaning of barriers to voluntarily lowering stigma and discrimination. It is a place to promote stigma reduction through home visits, radio, banner installations, and poetry readings. So promotion is a strategy to convey a message so as not to provide stigma or discrimination that tends to motivate behavioral sedation through engaging media and appropriate methods images, make simple words, inform all doubts in the community, do not save without resolution.

\section{The Effect of WPA's Role Optimization Program on Stigma and Discrimination in HIV/AIDS Patients in} the Community

The results showed there were significant differences in negative attitudes before and after the 
intervention with a significance level of $\mathrm{p}=0.049$. Contrast also be seen from negative attitudes that previously scored an average of 15.48 decreased to 14.07 , which means that their negative attitude reduced towards PLWHA; they are more optimistic. Likewise, each component of the negative attitude statement from an average score of 1.9 to 1.8 , and people who were undecided or agreed negative attitudes decreased from 14 to 8 people. There is a significant difference between discrimination felt before and after intervention value $\mathrm{p}=$ 0.006. We were also supported by data change in the average score of respondents before intervention 13.04. After the intervention of 11.63, the score of each statement before the moderate intervention was 2.2 and after that to 1.9. And 18 people who initially hesitated or still felt discrimination became 15 people.

There are significant differences in support of justice in PLWHA is before the intervention and after intervention with a provision of value $\mathrm{p}=0.000$. They reinforced by data on the average respondent's score before the intervention of 14.92. After 16.92 interventions then the score of each statement before the moderate intervention was 3.7. After that, it becomes 4.2. Fifteen people who were initially undecided or still did not support justice to 6 people.

Of the three indicators of the scale of stigma arise, doubts before and after the intervention. Reluctance is understood as uncertainty about the truth, skewed disbelief in the validity of a statement, a concern between yes or no, between opposing opinions. Doubts arise due to the many conflicts in society caused by a lack of socialization, perception, and clarification of the company. So can be reviewed from some answers from respondents who are still confused or doubtful. For example HIV there is a cure or not, they still believe HIV has no cure, they also have not stated, if asked to buy food from people with HIV are not willing, they advise that people with HIV sell edible goods. These doubts must continue to gain attention and will resolve if the optimization program implementation intensively.

The results of this study show that the concept of health promotion that integrates social support, social networking, and social marketing is reliable. The model describes social networking and social support as starting points or initiators that impact health. For example, social networking and social support can improve an individual's ability to access new contacts and information and to identify and resolve issues. Suppose the consent provided helps to reduce uncertainty and things that are difficult to predict or help produce the desired impact. So the sense of personal control over a particular situation will increase further.

The theory of symbolic interaction states that human behavior by on the meaning that people give to events. Society has a negative stigma meaning everything related to HIV is negative. The company indicates that this scary event, with no cure, can be contagious in a variety of ways. Therefore social support by policyholders must be done, through increased knowledge, information designed with social marketing. Social marketing is different from health education which mainly focuses on individuals, and the impact is the improvement of knowledge, attitude, skills. At the same time, social marketing targets consist of individuals, social, political leaders, professional societies. The impact is that behavior improves personal well-being, social, knowledge, attitudes, norms, values, and consumer self-image. All target to strengthen their informed behavioral decisions. Satisfaction is more likely to be delayed. Benefits tend to be long-term ${ }^{(11)}$. Especially appropriate when applied in HIV aids treatment.

\section{CONCLUSION}

Before and after the intervention, the average community did not show a negative attitude towards PLWHA, did not feel any discrimination in the city, and supported justice against PLWHA.

WPA's Role Optimization Program within the Reduction of Stigma and Discrimination in HIV AIDS Patients integrated the concept of social support, social network, and social marketing. The program has done with the following flow 1). Cross-sectoral coordination (Health Office of Blitar City, Counselor, Puskesmas, WPA Committee), 2) Made the group through WhatsApp group of WPA and KPA administrators. 3). Training of WPA Committee of Sananwetan Sub-District. 4). Radio Broadcast, 5). Installation of Banner 6) Evaluation of WPA performance and Stigma for HIV patients in society.

There are significant differences in negative attitudes towards PLWHA, perceived discrimination, and support for justice before and after the intervention.

The author's advice is that WPA administrators are expected to always coordinate with the KPA team and the Health Office for the sustainability of the program implementation, evaluating, and reporting the results obtained. In carrying out the program, KPA and The Health Office are always expected to provide support for the scheduled WPA Programs. The government in Blitar City is expected to provide adequate support.

\section{REFERENCES}

1. SidikMD, et al.. Panduan Praktis: Pelaksanaan Pengendalian HIV-AIDS Bagi Tahanan dan Warga Binaan Pemasyarakatan. Silitonga N, editor. Jakarta: Direktorat Jenderal Pemasyarakatan; 2017.

2. Satyabhakti P. Stigma, Diskriminasi, Faktor Budaya dan Sosial Ekonomi Terkait dengan HIV dan AIDS. 
Pelatihan HIV AIDS, Surabaya; 2012.

3. Dinas Kesehatan Kota Blitar. Situasi dan Kondisi AIDS kota Blitar: Laporan Tahun 2018. Blitar: Dinas Kesehatan Kota Blitar; 2018.

4. Kementerian Kesehatan RI. Panduan Hari AIDS Sedunia. Jakarta: Kementerian Kesehatan RI; 2017.

5. Haghdoost A, Karamouzian M. Zero New HIV Infections, Zero Discrimination, and Zero AIDS-Related Deaths: Feasible Goals or Ambitious Visions on the Occasion of the World AIDS Day? [Internet. 2012 [cited: 2020 May 12]. Available from: https://www.ncbi.nlm.nih.gov/pmc/articles/PMC3530298/

6. Siagian AV, et al. Rencana aksi Nasional Kolaborasi TB-HIV. Widaningrum C, Wiweko SN, editor. Jakarta: Kementerian Kesehatan RI; 2015.

7. Martiningsih W, Winarni S, Harsoyo S, Susatya B, Hariyanto T. The Lived Experiences of Caring Behavior among Nurses as Counselor of HIV/AIDS in Blitar City. 3rd SPUP Int Res Conf. 2017.

8. Pudjiastutik W. Social Marketing: Strategi Jitu Mengatasi Masalah Sosial di Indonesia. pertama. Jakarta: Yayasan Pustaka Obor Indonesia; 2016.

9. Genberg BL. A comparison of HIV/AIDS-related stigma in four countries: Negative attitudes and perceived acts of discrimination towards people living with HIV/AIDS. Soc Sci Med. 2009;68:2279-87.

10. Rachmat HH. Penguatan upaya Kesehatan Masyarakat dan Pemberdayaan Masyarakat Bidang Kesehatan di Indonesia. Yogyakarta: Gajah Mada University Press; 2018.

11. Levebvre RC. Social Marketing and Social Change: Strategi and Tools for Health, Well-Being, and the Environment. San Fransisco: Jossey-Bass; 2013. 